\title{
Blater, from Affinity to Tyranny? \\ The Phenomenon of Sole Candidacy in the 2015 Local Election in Blitar Regency, Indonesia
}

\author{
Wawan Sobari \\ Master Program of Social Science \\ Faculty of Social and Political Sciences (FISIP), Universitas Brawijaya \\ Malang, Indonesia \\ wawansobari@ub.ac.id
}

\begin{abstract}
Surveys on the direct election for local leader (pilkada) reveal that the popular leaders (who are close to the people) are most desirable, including among Javanese voters. Experts explain that those findings show evidence that there is functioning appearances-based inferences (image) constructed by politicians (Olivola and Todorov 2010). Lawson et al. (2010) assert that image is an influential arbiter of the success of politicians to gain positions public. In Indonesia, popularity and likeability are two factors contributing to high electability (Qodari 2010). Recent qualitative case study discovers that the personal construction of a regent candidate known as blater (friendly, easy to socialize) becomes the significant factor of popularity and likeability. Blater character represents the Javanese leadership philosophy of Prasaja and Manjing AjurAjer (want to live modestly and get along with ordinary people). In Javanese social relations, blater is the antithesis of elitist priyayi behavior. Moreover, blater is also compatible with Javanese wisdom, particularly for a Javanese leader, in order not to adigang (pride of power), adigung (pride of greatness), and adiguna (pride of skill and expertise). Beyond this excellent character of Javanese leader, blater has given rise to a tyranny leading to a sole candidate in the 2015 Blitar Regency election. Firstly, blater results in high popularity and likeability of the incumbent candidate and induces difficulties for potential challengers. Secondly, this situation encourages the rationality and opportunism of political parties in nominating regional heads, and finally to set a sole candidate. Lastly, citizens are persuaded to accept the election with the sole candidate as a condition of electoral democracy, although it limits the space for voting. Hence, pilkada with the sole candidate has eliminated the essence of democracy as a competitive arena of leaders' selection and space for expressing people choice. The absence of competition and capability to vote are two aspects negating the progress of democracy.
\end{abstract}

Keywords: Pilkada; Tyranny; Javanese Voters; Democracy; Blater; Local Politics

\section{BLATER, A FACTOR LEADING TO SOLE CANDIDACY IN PILKADA}

The decision of the Constitutional Court (MK) Number 100/PUU-XIII/2015 on the Election of Regional Head (Pilkada) with the sole candidate is a new fact in democratic practice in Indoenesia in the post-Suharto era. The only candidate in pilkada is contradictory to the general principles of democracy-promoting fair competition among candidates or political parties in a democratic election. The pilkada with the sole candidate dismisses competition for political leadership. Schumpeter (2013) makes the competition as one of the pillars of liberal democracy as "The democratic method is that institutional arrangement for arriving at political decisions in which individuals acquire the power to decide by means of a competitive struggle for the people's vote.".

The decision, then, allowed pilkada with the sole candidate in three regions, namely Blitar Regency (East Java), Tasikmalaya Regency (West Java) and North Central Timor (East Nusa Tenggara) to be conducted simultaneously with 266 other regions on December 9, 2015.

MK decided that the pilkada with a sole candidate aimed at asking people (voters) to express their approval or disapproval of the candidate. Consequently, if more voters disagreed, pilkada in the three regions were postponed on the next scheduled elections (2017) (following the Constitutional Court's decision No. 100 / PUU-XIII / 2015, 43-44).

The decision brought voters into a paradoxical situation, namely an absence of competitive struggle in the election. Or, in the study of democracy (quality of democracy), it had not met the principle of competitiveness.

Beyond the problem of the absence of competition, this study reveals an important factor supporting the phenomenon of the sole candidate in the 2015 pilkada in Blitar Regency. The case study discloses the reluctance of the canidates to run the 2015 pilkada. One of the reasons is the high electability of Vice-regent Rijanto (2010-2015) nominated as regent candidate by the Partai Demokrasi Indonesia Perjuangan (PDIP).

During his tenure as the deputy regent (2010-2015), Rijanto was known as a blater leader. Blater is an adjective meaning friendly or sociable. As a leader, Rijanto does not hesitate to get along and be close to the ordinary people (wong cilik).

Related to pilkada, the blater figure fits the ideal character of a leader. It revealed by various polls in Indonesia that voters want leaders who will close to the people (merakyat). A blater leader wants to hear people 
voices, especially wong cilik who had been perceived challenging to get closer to the people who hold power.

Consequently, the blater character had pushed Rijanto's electability to go ahead in the 2015 pilkada. The Government Policy Research Center (PK2P) released a poll (July 1, 2015) that Rijanto's electability reached 66.3 percent. Also, an internal survey of Partai Gerakan Indonesia Raya (Gerindra) conveyed that Rijanto's electability was higher than other candidates.

The two most relevant studies support this assumption. First, the comprehensive literature study conducted by Olivola and Todorov (2010) concludes that most voters are encouraged by the image of politicians when they make their choice. Moreover, their study found that voters refer to the appearance of candidates when determining the choice. The appearance-based inference of candidate's personality can predict the candidate's victory with high accuracy.

Second, Lawson et al. (2010) study echo Olivola and Todorov's findings that appearance is a powerful determinant of politicians' success. Their research in Mexico and Brazil found that voters refer their choice on obvious appeal of candidates.

In Indonesian context, the study and experience of political consultancy by Muhammad Qodari (2010) shows that the ownership of two personal attributes of candidates, high name recognition, and high likeability, encourage the possibility of the victory of the candidate. In other words, the high combination of these two attributes tends to be translated into high electability.

These studies are worth mentioning to explain the logic of high electability of an incumbent among voters. However, a local cultural explanation (Javanese) on the personal construction of an incumbent has been relatively absent in academic discussion. Also, this study seeks to expand the perspective on blater. It applies a different perspective by looking at blater's character as a tyranny in the construction of electability. First, tyranny limits candidates and political parties to compete in a democratic competition. Second, tyranny limits the space of citizens to vote.

\section{THE CASE STUDY}

This study applies qualitative research principles with interpretivism as its paradigm. It utilizes the case study as a research method, involving "an exploration of event, activity, and process of one or more individuals". To gather the qualitative data, the study utilized semi-structured interviews with voters who cast their vote in pilkada. The analysis is focused on 10 of 20 selected participants in two villages (Kertonegoro and Prapen) who argued for favoring blater as the reason to vote for Rijanto. It also deployed elite interviews with local politicians. The interviews were conducted at Kertonegoro Village (pseudonym) located in Kanigoro Sub-district and Prapen Village (pseudonym) located in Kesamben Sub-district.
Blitar is categorized as a Mataraman area since the major and indigenous population is Javanese. Also, Blitar's cultural feature is categorized as Java Mataraman in the East Java Regional Division of Culture. In other words, in the regional division of Javanese culture, these regencies are included in Mancanagari or "outer region." Mancanagari's culture is similar to the central Javanese court culture of Yogyakarta and Surakarta, with syncretism in religious life, unifying elements of Hinduism, Buddhism, and Islam. The folk culture and art of Blitar and Trenggalek are also similar to those of the two centers of Javanese culture.

\section{BLATER: AN IDEAL CHARACTER OF JAVANESE LEADER}

Rijanto is known to perform blater character while he served the vice-regent (2010-2015). This impression has been embedded in public mind throughout his career as a bureaucrat at the Government of Blitar Regency. Rijanto has served as a sub-district head in several sub-districts. His last position before nominating as vice-regent in the 2010 Pilkada was the head of Education Office. He was known to be close to the teachers and community. A senior local journalist delivered his observation:

Mr. Rijanto, a former sub-district head, civil servant, he has more chance to socialize or build image because his activities in local government made him meet many people.

In Javanese culture, blater can be explained from multiperspectives. Firstly, blater character represents the Javanese leadership philosophy of prasaja and manjing ajur-ajer (want to live modestly and get along with ordinary people). A leader who holds the philosophy of prasaja or prasodjo in his leadership is believed not to be mean to his people. The prasaja leader does not have an excessive desire (ora neka-neka) to take advantage of his position for personal gain.

The prasaja leader will always be simple in thinking, speaking and behaving. Thus, the attitude of the prasaja leader in Javanese philosophy is believed to form the personality of the leader who is andap asor (humble) (Yana MH 2012, 158). Therefore, the prasaja Javanese leader will be easy to unite with his people as depicted in the blater character belong to Rijanto. A local legislator clearly explained:

Many people know Pak Rijanto, the person who is "entengan" [to enjoy helping others]. He is friendly, never angry, and blater. He wants to attend; even he is invited by people at the neighborhood level [RT]. Whereas, in terms of performance [he] does not succeed, is there any breakthrough belong to Pak Rijanto? .

Another local legislator strengthened the statement:

The running local government [performance] is not very good. People judge [Rijanto] friendly, wants to greet, [easily] to meeting invitations. 
The Javanese Book of Basa Basuki teaches Javanese a polite language. Prasaja teaches how to speak in social intercourse with the same fellow or equal social level. Basa Basuki book teaches the practical understanding of communicating openly to the same. As an incumbent deputy regent, Rijanto was accustomed to using such simple language to his fellowmen. Rijanto is happy if his interlocutors (ordinary people) use language regardless of his status as a government official. Hence, he is considered blater because his words are prasaja when communicating with the community.

His ability to communicate with people is recognized by one of the Vice Chairman of Blitar Legislature:

Fairly, we see the level of Mr. Rijanto's popularity was high. But, we see no achievement. People see Mr. Rijanto is blater, and he has good communication skill.

The philosophy of manjing ajur ajer means the leader can adjust his personality, attitude, and actions to the people. A Javanese leader who is ajur ajer has a feeling of belonging to the people. This emotional closeness encourages Javanese leaders always attempt to protect and prosper the people. Another meaning of manjing ajur ajer is the specialty of puppet figures called Semar. He is known to be able to manjing ajur ajur or can be anyone. As a leader, Rijanto could become an ordinary people while hanging out with them.

As a manifestation of the attitude of prasaja and manjing ajur ajer, a Javanese leader has a willing to have face-toface chat with the people and one of them is done via blusukan (impromptu visit) activity. A leader visits local spots where people live and work. Rijanto's blusukan activities throughout his tenure as a bureaucrat (head of subdistrict and local office) and deputy regent made him known as blater.

Among voters, the manifestation of prasaja and manjing ajur ajer attitude is demonstrated in the form of closeness to the community. One of the heads of the neighborhood (RT) who is also the head of the farmer group in Kertonegoro Village testified, "This person (Rijanto) wants to be close to (ordinary) people. His approach to community is good".A female of the owner of small vendor (pracangan) in Kertonegoro met Rijanto when she joined with elderly to practice senam tera (gymnastic), "Mr. Rijanto is a good person. He wants to come to various activities. He joined in senam tera as well ".

In Javanese social relations, blater is an antithesis of elitist priyayi behavior. Clifford Geertz (1960) describes the identity of Javanese priyayi as white collar nobles. Most of them are bureaucrats, clerks, and teachers (1960, 229). Other scholars write similar explanations about priyayi identity, namely as local Javanese gentry; the elite of Javanese society; the Javanese bureaucratic elite; and Javanese aristocrat.

Geertz's work (1960) which became the reference of many circles explains that the priyayi has a position as the elite of noble descent and non-aristocratic (commoners pulled into the bureaucracy); and as having "religious life".
Concerning the findings of this study, priyayi identity (as an elite that practices alus etiquette) is a contrast with the populist blater's character.

Meanwhile, in Javanese social relations, priyayi tends to be exclusive because they are few in number and have social and governmental positions, which then categorized as elite. Also, the priyayi socially run a pair of concepts central to them, namely alus and kasar etiquette. The former means pure, refined, polished, polite, exquisite, ethereal, subtle, civilized, smooth which is opposite to the latter meaning impolite, rough, uncivilized, a bad music player, a stupid joke, a cheap piece of cloth attributed to the people. This opposite character provides a wall of etiquette providing alus priyayi "a set of rigidly formal ways of doing things which conceive his real feelings from others ....".

Alus etiquette distinguishes the behavioral order of priyayi and common people, including the Javanese language etiquette applied by priyayi. As the highest official in Blitar Government, Rijanto's behavior is not mriyayi (behave as priyayi). He used to hang out and talk to commoners and ignoring his status as an elite priyayi.

Rijanto's behavior that is close to the society can be known from his voters' explanations. A female street vendor, living at Prapen voting for agreeing on RijantoMarhaenis (Ridho) as the sole candidate at the December 9, 2015, pilkada, stated, "agree. The reason is we already know Mr. Rijanto. He often came to many activities".

A voter who also serves as the Secretary of Village Consultative Board (BPD) at Prapen said,

Because I have seen his actions that he always attends community activities, such as sholawatan and BPD's association meetings. Mr. Rijanto is sociable to community.

Rijanto possessed the second highest executive position in Blitar, but his exclusive position is in contrast to his leadership behavior that is close to the people. His attendance to fulfill invitations in many forums initiated by the public is an important proof making him called as blater.

Blater is also compatible with Javanese wisdom, especially for a Javanese leader, in order not to adigang (pride of power), adigung (pride of greatness), and adiguna (pride of skill and expertise). These words teach that Javanese are prohibited to be arrogant of whatever they have. The advice suggests that the Javanese must be humble to others. Particularly, adigang, adigung, adiguno teach leaders and leadership not to be arrogant, abusing power, and manipulating for personal gain.

The noble personality of the Javanese is embedded in Rijanto who is considered clean during he served as the vice-regent (2010-2015). A male teacher retirement at Prapen told his view, "Mr. Rijanto was a deputy regent. There was no 'negative smell' (no case) addressed to him during his era" he said. Blater is an individual appearance that is relevant to Javanese wisdom; Javanese leadership should be far from arrogant. A blater Rijanto is widely 
recognized among Blitar people. A local legislature clearly echoed what the society said about the blater Rijanto:

Many people know Pak Rijanto, the person who is "entengan" (to enjoy helping others). He is friendly, never angry, blater. Even if he is invited by people at the neighborhood level (RT), he wants to attend.

As a leader, people widely recognize that Rijanto is blater, since he is friendly and never angry. This character constructs an image that Rijanto is not adigang although he holds power as a high official. Blitar people enjoy this character, although his leadership achievement is not excellent.

Based on the explanations of voters and local elites, Rijanto successfully constructed, intentionally or not, the ideal Javanese leader's character of blater. First, Rijanto seeks to interact directly (chatting) with people. His willingness to interact and communicate directly with the community, especially when serving as vice-regent (20102015), constructed the image of Rijanto closeness with the people. When Rijanto attended all community invitations for various activities, he indirectly embedded blater image among people.

Also, Rijanto's ability to adjust his behavior and language when meeting ordinary people demonstrate his closeness to society. Rijanto left his status as government elite to meet the community.

Second, Rijanto's image as a clean power holder constructs his blater character.

Finally, blater was able to cover up the performance of Rijanto that was not as better as his popularity among people. Some local elites considered Rijanto's leadership performance was unable to foster progress acceleration in the regency.

\section{BLATER, LEADING TO A TYRANNY?}

The first question asked to voters regarding their knowledge/opinion related to the 2015 Pilkada with the sole candidate. Voters stated that the pilkada with sole candidate did not give enough space to vote. In other words, they tend to be forced to agree or disagree with a candidate pair without doing a comparative assessment. A 45-year-old female, head of a kindergarten based in Kertonegoro, expressed her opinion:

It was harder to see the right criterion. It was harder because the person (the candidate) was just one. I have to consider better. Why there is no other candidates? Suppose it (presented) more than one candidate, the comparison was easier .

A similar opinion was conveyed by participants at Prapen Village. A male participant (41 years old), a farmer and a construction worker expressed his opinion on the compulsion to vote:

I ask why only one candidate, no others. Yes, we have to vote for it, because there is no other candidates ... Yes (I was) forced to vote for, rather than no (do not have) leader .

A female participant (41 years old), a housewife at Prapen delivered a more critical opinion:

I think it was strange, pilkada usually (provides) other options. If only one (candidate) agree or disagree. If you agree, it is not necessarily in accordance with the choice. If you do not agree there is no other choice ... the next pilkada must have the challenger. Do not just agree or disagree, seem to be forced .

Opinions explained by the participants demonstrate the meaningless implementation of pilkada with the sole candidate. Voters cannot express their decision to vote due to limited choice.

Interviews with participants also illustrate the strength of the incumbent blater effect. First, the participants vote for agree because they had known Rijanto during he served as deputy regent (2010-2015). A female participant (64 years old), small vendor at Kertonegoro and she was active in senam tera which usually attended by Rijanto, stated "Agree. Mr. Rijanto has been holding activities (position as deputy regent) in the Regency."

At Prapen, the same reason was also expressed by participants. A male participant (50 years old), graduated senior high school and a small entrepreneur explain his reason to vote for:

Agree. As a citizen, if there is no leader we must vote. I have also seen his actions (Rijanto), always attending community activities, such as sholawatan and BPD's association meetings. Mr. Rijanto is sociable to community.. . [Rijanto] is suitable for Blitar, for a better future expectation".

Thus, the popularity and likability of the incumbent helped residents to vote for agreeing for the sole candidate.

Another reason for agreeing to the sole candidate is because there is no other choice, rather than having no leader. This reason is different with the intention of the MK's decision to request people opinion to agree or not with the candidate. It does not mean that people will not have a leader supposed the majority of voters vote for disagreeing.

A female tailor (40 years old) at Kertonegoro voted for agreeing with the sole candidate rather than having no leader "Agree, If do not agree, who will run the Blitar Regency," he briefly said.

The same reason delivered by a male participant ( 55 years old), a builder, at Prapen firmly conveyed his dilemma if he did not vote for agrees on option, "Agree. If (I do) not agree, there will be no pilkada. If I do not agree, there will be no regent later," he mentioned.

\section{CONCLUSION}

This study reveals several significant findings. First, the level of popularity and likeability of the incumbent was high. 
In addition to local people who have already known him, they also favored the incumbent's leadership behavior which is communicative and has no distance with people (blater). Otherwise, other elites who desired to nominate in the 2015 pilkada did not possess the similar political characters.

Second, the superiority of blater characters encourages political parties' maneuvers to compete to nominate Rijanto. This situation, then, leads to the impasse of political negotiations among parties. Rijanto eventually was nominated by PDIP and encouraged other political parties to form a coalition that ultimately agreed not to nominate candidate pairs.

The high level of recognition and likeability (electability) of citizens to Rijanto encouraged other parties to consider delaying the pilkada until 2017. Parties found that the closeness of citizens with Rijanto as an incumbent would decrease with the replacement of regent by a temporary official (pelaksana tugas) until 2017.

Finally, parties and candidates who want to challenge the blater incumbent must spend the high political costs. The potential for massive candidacy expenditures on the one hand and the difficulty of defeating the blater incumbent, on the other hand, led to the political rationality of political parties and candidates not to run in the pilkada.

\section{IMPLICATION}

Citizens are those who are most affected by pilkada with the sole candidate. The democracy that should be a competitive selection mechanism of candidates for public officials does not work. People are confronted with the choice of agreeing or disagreeing with a sole candidate.

Therefore, the blater phenomenon has indirectly forced an absence of a choice room. For citizens, then, democracy is done by devoting practice, rather than democracy by choice (enhancing the capability of choosing).

The sole candidate in pilkada has reduced the quality of democracy. It is contradictory to the general principle of democracy providing fair and competitive space (competitiveness) for candidates in an election. The sole candidate sparks no competition for political leadership.

For measuring the progress of democracy in Indonesia, pilkada with the sole candidate need to be considered as a variable negating the advance of democracy.

\section{ACKNOWLEDGEMENT}

I would like to deliver my sincere thankfulness to the Ministry of Research and Higher Education of the Republic of Indonesia (KEMENRISTEK DIKTI) and Brawijaya University for funding this study. The fieldwork was supported by the 2016 Bantuan Operasional Perguruan Tinggi Negeri (Higher Education Operational Fund, BOPTN). The content of the article is the author's entire responsibility and the views and opinions it contains do not represent KEMENRISTEK DIKTI and Universitas Brawijaya.

\section{REFERENCES}

[1] D. Altman and A. Pérez-Liñán, "Assessing the quality of democracy: Freedom, competitiveness and participation in eighteen Latin American countries," Democratization, vol. 9(2), pp. 85-100, 2002.

[2] S.A. Andreev, "Conceptual definitions and measurement indicators of the quality of democracy: an overview", Working Paper of the Robert Schuman Centre, 2005.

[3] S. Arimi, "Pergeseran kekuasaan bangsawan jawa indonesia: sebuah analisis wacana kritis", Jurnal Masyarakat dan Budaya, vol. 10(2), pp.1-22, 2008.

[4] B. Baker, "Quality Assessment of Democracy in the "Third World'," in Democracy and Political Change in the Third World, 2001, pp. 21-34.

[5] J. W. Creswell, Research Design: Qualitative, Quantitative, and Mixed Methods Approaches. Thousand Oaks, California: Sage Publications, 2009.

[6] N. K. Dewi, "Pengembangan Model Bimbingan Kelompok Berbasis Nilai Karakter Lokal Jawa untuk Meningkatkan Kesadaran Diri (Self Awareness) Siswa," Counsellia: Jurnal Bimbingan dan Konseling, vol. 3(1), 2016.

[7] M. Erb and P. Sulistiyanto (Eds), Deepening democracy in Indonesia?: direct elections for local leaders (Pilkada), Singapore: Institute of Southeast Asian Studies, 2009.

[8] C. Geertz, The Religion of Java, London: The Free Press of Glencoe, 1960.

[9] S. Endraswara, Falsafah Kepemimpinan Jawa: Butir-Butir Nilai yang Membangun Karakter Seorang Pemimpin Menurut Budaya Jawa, Yogyakarta: Narasi, 2013.

[10] A. Fanani, "Identitas dan mobilitas sosial priyayi dalam novel para priyayi karya umar kayam," Sabda: Jurnal Kajian Kebudayaan, vol. 12(1), pp. 42-51, 2017.

[11] Koentjaraningrat, Javanese Culture, Singapore: Oxford University Press, 1985.

[12] C. Lawson, G. S. Lenz, A. Baker, and M. Myers, "Looking like a winner: Candidate appearance and electoral success in new democracies," World Politics, vol. 62(4), pp. 561-593, 2010.

[13] C. Y. Olivola and A. Todorov, "Elected in 100 milliseconds: Appearance-based trait inferences and voting," Journal of Nonverbal Behavior, vol. 34(2), PP. 83-110, 2010.

[14] M. Picard and R. Madinier (Eds.), "The politics of Religion in Indonesia: Syncretism, orthodoxy, and religious contention in Java and Bali," Routledge, 2011.

[15] B. Pranowo, "Islam and party politics in rural Java," Studia Islamika, vol. 1(2), pp. 1-19, 1994.

[16] M. Qodari, "The professionalisation of politics: The growing role of polling organisations and political consultants," in Problems of democratisation in Indonesia: Elections, institutions and society, Singapore: ISEAS, 2010, pp. 122140.

[17] Republik Indonesia. Putusan Mahkamah Konstitusi (MK) Nomor 100/PUU-XIII/2015 tentang Pemilihan Kepala Daerah dengan Hanya Satu Pasangan Calon.

[18] A. I Rozuli, "Demokrasi, Pembangunan dan Pemilukada: Teori, Konsep, dan Implementasi," unpublished.

[19] J. A. Schumpeter, Capitalism, socialism and democracy, Routledge, 2013. 
[20] A. Sutarto and S.Y Sudikan (eds.), Pemetaan Kebudayaan Propinsi Jawa Timur: Sebuah Upaya Pencarian Nilai-Nilai Positif, Jember: Biro Mental Propinsi dan Kompawisda Jatim, 2008.

[21] S. Tjahyadi, "Dekonstruksi pemahaman budaya jawa tentang hakikat dan hubungan kawula-gusti pada lakon wayang " Semar Kuning"," Jurnal Filsafat, vol. 19(2), pp. 103-125, 2009.

[22] T. Widiatmi, "Ajaran kesantunan berbahasa dalam serat basa basuki," Prosiding Prasasti, pp. 821-824, 2016.

[23] M. H.Yana, Falsafah dan Pandangan Hidup Orang Jawa, Yogyakarta: Bintang Cemerlang, 2012. 